\title{
Canine cutaneous neoplasms in the metropolitan region of Goiânia, Goiás state, Brazil ${ }^{1}$
}

\author{
Igor R. Santos ${ }^{2}$ (D) Ana C.M.P. Lima ${ }^{2}$, Hugo H. Ferreira 3 , Brunna R. Rezende ${ }^{4}$, \\ Anderson R. Silva ${ }^{5}$ and Adriana S. Santos ${ }^{2 *}$ (i)
}

\begin{abstract}
Santos I.R., Lima A.C.M.P., Ferreira H.H., Rezende B.R., Silva A.R. \& Santos A.S. 2020. Canine cutaneous neoplasms in the metropolitan region of Goiânia, Goiás state, Brazil. Pesquisa Veterinária Brasileira 40(8):614-620. Laboratório de Histologia e Patologia Animal, Instituto Federal Goiano, Campus Urutaí, Rodovia Geraldo Silva Nascimento Km 2,5, Zona Rural, Urutaí, G0 75790-000, Brazil. E-mail: adriana.santos@ifgoiano.edu.br

The present study aimed to describe the occurrence and epidemiological features of skin neoplasms diagnosed in dogs in the metropolitan region of Goiânia, Goiás state, Brazil. Diagnoses from dog biopsies from 2011 to 2016 provided by a private veterinary pathology laboratory were analyzed. The main diagnoses were mast cell tumor, hemangiosarcoma, squamous cell carcinoma, malignant melanoma, and hemangioma. Highest frequency of neoplasms was found in female dogs, dogs aged $>8$ years, and purebred dogs, particularly the American Pit Bull Terriers and the Poodles. Most common sites affected by the neoplasms were the limb and the head. Using multiple correspondence analysis, groups of neoplasms were found to be associated with different epidemiological features and the size of the neoplasms was associated with the biological behavior. The results of this study described predispositions and verified the importance of different types of skin neoplasms in dogs in the region being studied.
\end{abstract}

INDEX TERMS: Canine, cutaneous neoplasms, Goiás state, Brazil, dermatopathology, dogs, skin, skin tumors.

\begin{abstract}
RESUMO.- [Neoplasias cutâneas caninas na região metropolitana de Goiânia, Goiás, Brasil.] O objetivo deste estudo foi determinar a prevalência e as características epidemiológicas das neoplasias cutâneas em cães na região metropolitana de Goiânia, Goiás. Foram analisados os diagnósticos de um laboratório do setor privado de 2011 a 2016. Mastocitoma, hemangiossarcoma, carcinoma de células escamosas, melanoma maligno e hemangioma representaram os principais diagnósticos. A maioria dos casos ocorreram em cães de raças definidas, fêmeas e com idade $>8$ anos. American Pit Bull Terrier e Poodle foram as raças mais
\end{abstract}

\footnotetext{
${ }^{1}$ Received on March 7, 2020.

Accepted for publication on March 20, 2020.

${ }^{2}$ Laboratório de Histologia e Patologia Animal, Instituto Federal Goiano, Campus Urutaí, Rodovia Geraldo Silva Nascimento Km 2,5, Zona Rural, Urutaí, G0 75790-000, Brazil. *Corresponding author: adriana.santos@ifgoiano.edu.br

${ }^{3}$ Veterinarian, Rua 54 142, Jardim Goiás, Goiânia, GO 74810-220, Brazil.

${ }^{4}$ Departamento de Produção e Melhoramento Vegetal, Faculdade de Ciências Agronômicas, Universidade Estadual Paulista "Júlio de Mesquita Filho" (Unesp), Rua José Barbosa de Barros 1780, Jardim Paraíso, Botucatu, SP 18610-307, Brazil.

${ }^{5}$ Laboratório de Estatística e Geoprocessamento, Instituto Federal Goiano, Campus Urutaí, Rodovia Geraldo Silva Nascimento Km 2,5, Zona Rural, Urutaí, GO 75790-000, Brazil.
}

encontradas. As neoplasias acometeram principalmente regiões de membros e cabeça. Pela análise de correspondência múltipla, associou-se os grupos de neoplasias com diferentes características epidemiológicas e o tamanho da neoplasia com o comportamento biológico. A comparação dos resultados com pesquisas prévias possibilitou confirmar predisposições previamente descritas e verificar a importância dos diferentes tipos de neoplasias cutâneas em cães na região estudada.

TERMOS DE INDEXAÇÃO: Neoplasia cutânea, caninos, Goiás, Brasil, cão, dermatopatologia, pele, tumores cutâneos.

\section{INTRODUCTION}

Understanding the most common lesions affecting the animals in a particular region is an important tool in diagnostic investigation. Prevalence of canine cutaneous neoplasms has been reported in several countries. However, these studies showed differences in the frequency of different types of neoplasms (Bostock 1986, Rothwell et al. 1987, Dobson et al. 2002, Kaldrymidou et al. 2002, Pakhrin et al. 2007, Graf et al. 2018). These differences may be justified by the interference of environmental factors (Souza 2005) and the dog breeds in the respective regions. 
In Brazil, regional studies were performed in several states such as Bahia (Machado et al. 2018), Mato Grosso (Lima et al. 2018), Ceará (Bastos et al. 2017), Minas Gerais (Fernandes et al. 2015), São Paulo (Scattone \& Fava 2014), Paraíba (Andrade et al. 2012), Rio de Janeiro (Silva et al. 2011), Rio Grande do Sul (Souza et al. 2006, Meirelles et al. 2010), and Paraná (Nardi et al. 2002). However, epidemiological data about canine skin neoplasms in the Goiás state are scarce.

The aim of present study was to describe the occurrence and epidemiological features of skin neoplasms diagnosed in dogs in the metropolitan region of Goiânia, Goiás state, Brazil.

\section{MATERIALS AND METHODS}

The present study was conducted at "Laboratório de Histologia e Patologia Animal" of "Instituto Federal Goiano", Campus Urutaí. The authors analyzed the reports from dog biopsy samples between 2011 and 2016 provided by a private veterinary pathology laboratory located in Goiânia, Goiás state. Information related to the histological diagnosis, breed, age, sex, size, and anatomical location of the neoplasms was obtained. For this study, primary cases of mammary neoplasms were excluded.

Original histological classification of the reports was considered, with standardization, when necessary, according to Goldschmidt \& Goldschmidt (2017), Hendrick (2017), and Kiupel (2017) classifications. Neoplasms were grouped into epithelial neoplasms (subdivided into epidermal neoplasms, sebaceous gland neoplasms, hair follicle neoplasms, and apocrine glands neoplasms), mesenchymal neoplasms (subdivided into vascular neoplasms, adipose tissue neoplasms, connective fibrous tissue neoplasms, and other mesenchymal neoplasms), round cell tumors, and melanocytic neoplasms.

According to the anatomical locations, neoplasms were categorized into those of head, neck, thorax, abdomen, limbs, perineum, scrotum, tail, and multiple locations (Fernandes et al. 2015). When more than one histological classification of cutaneous neoplasms were identified, each classification was considered separately. Age groups of the animals were $<1$ year, 1-8 years, and $>8$ years (Souza et al. 2006).

Descriptive statistical analyses were used to evaluate the data. Additionally, multiple correspondence analysis was performed using R software (R Core Team, 2019) . The following associations were tested: i) groups of neoplasms with anatomical locations, ii) groups of neoplasms with age and sex (males $<1$ year, males 1-8 years, males $>8$ years, females $<1$ year, females $1-8$ years, and females $>8$ years), and iii) size $(<1 \mathrm{~cm}, 1-2 \mathrm{~cm}, 3-4 \mathrm{~cm}$, and $>5 \mathrm{~cm})$ with biological behavior (benign and malignant). Results were presented in twodimensional perception maps and Fisher's exact test was applied to the contingency tables to verify significant associations $(p<0.05)$.

\section{RESULTS}

\section{Dataset}

From 2011 to 2016, 4336 canine tissue samples were received. Out of these, 2138 (49.3\%) were from the skin and 1266 (59.2\%) among the skin samples were diagnosed with cutaneous neoplasms. Fifty-nine (4.9\%) out of the 1200 reports analyzed in this study reported that the animal had at least two histologically different cutaneous neoplasms.

\section{Types of neoplasms}

Neoplasms of epithelial origin $(32.9 \%, n=417)$ were the most prevalent, followed by mesenchymal neoplasms $(30.0 \%$, $n=380)$, round cell tumors $(28.3 \%, n=359)$, and melanocytic neoplasms (8.6\%, $\mathrm{n}=110)$. Among the epithelial neoplasms, $35.9 \%(n=150)$ were from the epidermis, $32.8 \%(n=137)$ from the sebaceous glands, $20.1 \%(n=84)$ from the hair follicles, and $10.0 \%(n=42)$ from the apocrine glands. Vascular neoplasms $(63.6 \%, n=242)$, adipose tissue neoplasms (13.4\%, $n=51)$, and connective tissue neoplasms $(7.8 \%, \mathrm{n}=30)$ were the prevalent mesenchymal neoplasms.

Frequencies and epidemiological aspects of the 48 types of neoplasms diagnosed in this study are presented in Table 1. The most frequent types of individual neoplasms were mast cell tumor (14.9\%, $n=189)$, hemangiosarcoma $(13.6 \%, n=173)$, squamous cell carcinoma $(8.4 \%, \mathrm{n}=107)$, malignant melanoma $(7.0 \%, \mathrm{n}=89)$, hemangioma $(5.1 \%, \mathrm{n}=65)$, histiocytoma $(4.3 \%$, $\mathrm{n}=55)$, lipoma $(3.7 \%, \mathrm{n}=47)$, hepatoid gland adenoma $(3.6 \%$, $\mathrm{n}=46)$, trichoblastoma $(3.5 \%, \mathrm{n}=45)$, and papilloma $(2.8 \%$, $\mathrm{n}=36)$. These 10 types of neoplasms represented $67.2 \%$ $(n=852)$ of all neoplasms.

\section{Distribution of neoplasms according to breed}

Information about the animal breed was found in 1177 (92.9\%) reports out of 1266 cases of cutaneous neoplasms. Purebred dogs $(73.4 \%, \mathrm{n}=930)$ had more neoplasms than mixed-breed dogs (19.5\%, $\mathrm{n}=247)$. The most affected breeds were American Pit Bull Terrier (15.8\%, n=201), Poodle (6.7\%, $\mathrm{n}=85)$, Dachshund (6.2\%, n=79), Boxer (6.0\%, n=76), Shih Tzu (5.0\%, n=64), Labrador Retriever (3.6\%, n=46), Pincher $(3.3 \%, n=43)$, English Cocker Spaniel $(3.1 \%, n=40)$, Yorkshire Terrier (1.9\%, $n=25)$, and Rottweiler (1.8\%, n=23). Description of these breeds according to the histological diagnoses is presented in Table 2 .

Breeds not included in Table 2 due to low number of cases were Schnauzer $(1.7 \%, n=22)$, Basset Hound $(1.5 \%, n=20)$, Golden Retriever (1.4\%, $n=18)$, Lhasa Apso (1.4\%, $n=18)$, Brazilian Mastiff (1.2\%, n=16), Chinese Shar Pei (1.1\%, $n=15)$, Pug (1.1\%, n=14), Maltese (0.8\%, n=11), German Shepherd $(0.7 \%, n=10)$, Brazilian Terrier $(0.7 \%, n=9)$, Beagle $(0.6 \%$, $\mathrm{n}=8)$, French Bulldog $(0.5 \%, \mathrm{n}=7)$, Bull Terrier $(0.5 \%, \mathrm{n}=7)$, West Highland White Terrier $(0.4 \%, n=6)$, Dogo Argentino $(0.4 \%, \mathrm{n}=6)$, and 21 other breeds with an occurrence of less than $0.4 \%(n<6)$.

Distribution of neoplasms according to anatomical location

Only $889(70.2 \%)$ reports contained data about the anatomical location of the skin neoplasms. Among these, $22.2 \%(n=198)$ were localized to the limbs, $22.2 \%(n=198)$ to the head, $19.6 \%(n=175)$ to the perineum, $13.3 \%(n=119)$ to the abdomen, $5.3 \%(n=48)$ to the thorax, $5.0 \%(n=45)$ to the neck, 3.9\% $(n=35)$ to the scrotum, and $1.3 \%(n=12)$ to the tail. Neoplastic lesions in multiple locations were found in $6.6 \%(n=59)$ of the cases. Three most frequent neoplasms in each location are shown in the Table 3.

\section{Distribution of neoplasms according to age}

The data included neoplasms from dogs aged 3 months to 19.5 years. Among the samples in which age was reported $(80.2 \%, n=1016), 50.7 \%(n=516)$ were from dogs aged $>8$ years, $38.3 \%(n=486)$ from dogs aged $1-8$ years, and only $1.3 \%$ $(\mathrm{n}=14)$ from dogs aged $<1$ year. The most prevalent neoplasms in dogs aged $>8$ years were mast cell tumor $(15.6 \%, n=81)$, hemangiosarcoma $(13.3 \%, \mathrm{n}=69)$, and malignant melanoma $(9.4 \%, n=49)$. The most prevalent neoplasms in dogs aged 1-8 
Table 1. Canine cutaneous neoplasms in the metropolitan region of Goiânia, Goiás state, Brazil and the distribution of the neoplasms according to mean age (years), breed, anatomical location, and sex



Other mesenchy. neoplasms 


\begin{tabular}{|c|c|c|c|c|c|}
\hline Neoplasm type & Number (\%) & Mean age & Breed (\%) & Anatomical location (\%) & Sex (\%) \\
\hline Peripheral nerve she. tumor & $14(66.6)$ & 8.7 & Mixed (42.8) & Limbs (57.1) & $\mathrm{F}(57.1)$ \\
\hline Osteosarcoma & $3(14.2)$ & 6.3 & * & Abdomen/Thorax (33.3) & $F(100)$ \\
\hline Condrosarcoma & $1(4.7)$ & 6 & Pit Bull (100) & Limbs (100) & M (100) \\
\hline Leiomyoma & $1(4.7)$ & 9 & Shih Tzu (100) & Perineum (100) & $F(100)$ \\
\hline Mast cell tumor & $189(52.6)$ & 8.5 & Mixed (26.9) & Limbs (23.2) & $F(61.3)$ \\
\hline Histiocytoma & $55(15.3)$ & 4.2 & Mixed (14.5) & Head (36.3) & $M(67.2)$ \\
\hline Lymphoma & $25(6.9)$ & 7 & Mixed (16) & Multiple (60) & M (56) \\
\hline Plasmacytoma & $23(6.4)$ & 8.4 & Mixed/Pit Bull (17.3) & Limbs (43.4) & $\mathrm{M}(52.1)$ \\
\hline Maligant melanoma & $89(80.9)$ & 9.5 & Mixed (24.7) & Head (21.3) & $F(53.9)$ \\
\hline Melanocytoma & $21(19)$ & 9.7 & Dachsh./Pit Bull (23.8) & Head (23.8) & $\mathrm{F}(57.1)$ \\
\hline
\end{tabular}

cerumi. $=$ Ceruminous, Cocker $=$ English Cocker Spaniel, con. $=$ connective, Dachsh. $=$ Dachshund, Dalmat. $=$ Dalmatian, $\mathrm{F}=$ female, Golden $=$ Golden Retriever, ke. = keratinizing, Labrador $=$ Labrador Retriever, $\mathrm{Ni}=$ not informed, $\mathrm{NS}=$ not specified, $\mathrm{M}=$ male, Malignan. = Malignant, mesenchy. $=$ mesenchymal, Pit Bull $=$ American Pit Bull Terrier, she. $=$ sheath, vener. $=$ veneral; $*$ there are at least three specifications with the same occurrence.

Table 2. Ten most common breeds with canine cutaneous neoplasms in the metropolitan region of Goiânia, Goiás state, Brazil and the distribution of the main histological diagnoses

\begin{tabular}{ll}
\hline Breed & \multicolumn{1}{c}{ Main morphological diagnoses (\%) } \\
\hline Pit Bull & Hemangiosarcoma (38.8) \\
& Squamous cell carcinoma (18.4) \\
& Hemangioma/Mast cell tumor (10.4) \\
Poodle & Trichoblastoma/Hepatoid gland adenoma (9.4) \\
& Squamous cell carcinoma (8.2) \\
& Lipoma/Mast cell tumor (5.8) \\
Dachshund & Maligant melanoma (16.4) \\
& Mast cell tumor (8.8) \\
& * \\
Boxer & Mast cell tumor (25) \\
& Hemangiosarcoma (15.7) \\
Shih Tzu & Squamous cell carcinoma (13.1) \\
& Tristiocytoma (10.9) \\
& Hepatoid gland adenoma/Meibomian adenoma (7.8) \\
Labrador & Mast cell tumor (23.9) \\
& Squamous cell carcinoma (8.6) \\
& Meibomian adenoma/Trichoepithelioma (6.5) \\
Pinscher & Mast cell tumor (37.2) \\
& Maligant melanoma/Hemangiosarcoma (13.9) \\
& Hemangioma (6.9) \\
Cocker & Lipoma (15) \\
& Trichoblastoma (10) \\
& Mast cell tumor (7.5) \\
Yorkshire & Papilloma (16) \\
& Mast cell tumor/Histiocytoma (12) \\
& Malingant melanoma/Trichoblastoma (8) \\
& Lipoma/Maligant melanoma (16.6) \\
& Lymphoma/Hemangiosarcoma (8.3) \\
& $*$
\end{tabular}

Cocker $=$ English Cocker Spaniel, Labrador $=$ Labrador Retriever, Pit Bull $=$ American Pit Bull Terrier, Yorkshire = Yorkshire Terrier; * there are at least three specifications with the same occurrence. years were mast cell tumor $(15.4 \%, \mathrm{n}=75)$, hemangiosarcoma $(14.6 \%, n=71)$, and squamous cell carcinoma $(8.8 \%, n=43)$. Histiocytoma alone represented more than half $(57.1 \%, \mathrm{n}=8)$ of the neoplasms in dogs aged $<1$ year.

\section{Distribution of neoplasms according to sex}

Among the samples, $51.8 \%(n=656)$ were female and $45.4 \%(n=576)$ were male. Sex was not reported in 34 samples (2.6\%). The most common diagnoses in females were mast cell tumor $(17.6 \%, n=116)$, hemangiosarcoma $(12.6 \%, n=83)$, squamous cell carcinoma $(8.0 \%, n=53)$, malignant melanoma $(7.3 \%, \mathrm{n}=48)$, and lipoma $(5.6 \%, \mathrm{n}=37)$. The most common diagnoses in males were hemangiosarcoma $(14.2 \%, n=82)$, mast cell tumor $(12.1 \%, \mathrm{n}=70)$, squamous cell carcinoma $(8.5 \%, n=49)$, malignant melanoma $(6.4 \%, n=37)$, and hepatoid gland adenoma $(6.4 \%, n=37)$.

\section{Multiple correspondence analysis}

Groups of neoplasms showed a significant association $(\mathrm{p}<0.01)$ with anatomical locations, age, and sex. Head, perineum, and tail were associated with epithelial neoplasms; abdomen with mesenchymal and melanocytic neoplasms; and limbs, thorax, scrotum, and multiple locations with round cell tumors. Irrespective of sex, dogs aged $<1$ year were more likely to develop round cell tumors and dogs aged $>8$ years were more likely to develop mesenchymal and melanocytic neoplasms. Dogs aged 1-8 years and the neck location showed a random relationship with the groups of neoplasms.

Among the neoplasms, 56.1\% $(\mathrm{n}=711)$ were malignant and $33.5 \%(n=425)$ were benign. Non-specified neoplasms and epitheliomas were excluded. Size of the neoplasms was mentioned in $19.8 \%(n=251)$ reports. A significant association was observed between the size and the biological behavior $(\mathrm{p}<0.01)$, where neoplasms with sizes $<1 \mathrm{~cm}$ presented a higher association with benign behavior and those with sizes 
Table 3. Main histological diagnoses according to the anatomical locations of canine cutaneous neoplasms in the metropolitan region of Goiânia, Goiás state, Brazil

\begin{tabular}{ll}
\hline Anatomical location & Main morphological diagnoses (\%) \\
\hline Limbs & Mast cell tumor (22.2) \\
& Hemangiosarcoma (7) \\
& Squamous cell carcinoma (6) \\
Head & Meibomian adenoma (12.1) \\
& Histiocytoma (10.1) \\
& Maligant melanoma (9.5) \\
Perineum & Hemangiosarcoma (21.7) \\
& Hepatoid gland adenoma (21.1) \\
Abdomen & Squamous cell carcinoma (10.2) \\
& Hemangiosarcoma (28.5) \\
Multiple & Squamous cell carcinoma (16.8) \\
& Maligant melanoma (12.6) \\
Thorax & Lymphoma (25.4) \\
& Hemangiosarcoma (23.7) \\
& Mast cell tumor (13.5) \\
Neck & Mast cell tumor (25) \\
& Lipoma (14.5) \\
& Histiocytoma (12.5) \\
Scrotum & Hemangioma (15.5) \\
& Mast cell tumor/ Trichobastoma (11.1) \\
Tail & Histiocytoma (6.6) \\
\hline * There are at least three specifications with the same occurrence. \\
Mast cell tumor (54.2) \\
\end{tabular}

$>5 \mathrm{~cm}$ showed a higher association with malignant behavior. Neoplasms with sizes of $1-2 \mathrm{~cm}$ and $3-4 \mathrm{~cm}$ were associated with both types of biological behaviors.

\section{DISCUSSION}

In the present study, we analyzed 1266 skin neoplasms in dogs in the metropolitan region of Goiânia, Goiás state, Brazil. The data was derived from a single pathology laboratory in the region. Although the prevalence of lesions diagnosed in other laboratories may have similarities with this study, we assume that the exposed results are underestimated. It is also known that not every cutaneous tumor in dogs is sent for histological analysis.

About $9.8 \%$ of the dogs in this study had more than one skin neoplasms, irrespective of whether they were of the same histological type. Similar results were found in other studies, adding the chance of occurrence of non-neoplastic tumors (Souza et al. 2006, Machado et al. 2018). These data highlight the importance of the clinical veterinarians and the veterinary surgeons sending samples of all skin tumors for histological analysis, despite the possibility that they are of the same histological type.

Skin tissue samples comprised of almost $50 \%$ of all canine samples during the period under evaluation. Previous studies have shown that skin lesions constitute the highest number of pathological diagnoses in dogs (Meirelles et al. 2010, Silva et al. 2011, Graf et al. 2018, Machado et al. 2018). Neoplastic lesions can range from $49.9 \%$ to $75.8 \%$ of all skin lesions (Souza et al. 2006, Machado et al. 2018), a finding similar to the results found in the present study.
The high prevalence of skin neoplasms in dogs may be related to factors specific to the species such as genetic predisposition (Lima et al. 2018), and factors related to tutors such as ease of observation of the lesions (Goldschmidt \& Goldschmidt 2017). Moreover, skin has a high rate of cell regeneration (Murphy 2006), is formed from numerous components in its structure (Bastos et al. 2017), and is directly exposed to oncogenic conditions (Martinez et al. 2006).

Epithelial neoplasms were the most common neoplasms in dogs in the studied region. Although round cell tumors are known to be of mesenchymal origin (Hendrick 2017), our criteria for classifying the neoplasm groups according to cell origin were defined to assist in the clinical diagnostic routine. In studies using a similar division of groups, round cell tumors (Graf et al. 2018) and mesenchymal neoplasms (Lima et al. 2018) presented high frequencies of $33.0 \%$ and $41.0 \%$, respectively.

Regarding analysis of the relative frequency of the types of neoplasms, our results are partially similar to previous studies. Mast cell tumor is described as the main cutaneous neoplasm in dogs (Bostock 1986, Mukaratirwa et al. 2005, Graf et al. 2018, Lima et al. 2018) and has a multifactorial etiology (Welle et al. 2008). The high occurrence of mast cell tumor in this study may be associated with the number of samples evaluated from dogs with racial predisposition such as Boxers and Labrador Retrievers (Dobson et al. 2002).

Squamous cell carcinoma, hemangioma, and hemangiosarcoma are among the most common canine cutaneous neoplasms in other Brazilian states (Andrade et al. 2012, Fernandes et al. 2015, Lima et al. 2018). However, they have low prevalence in other countries (Bostock 1986, Pakhrin et al. 2007, Graf et al. 2018). The frequency of these neoplasms in dogs has a direct association with geographical location, as they are associated with prolonged sun exposure and breeds with little skin pigmentation and short hair (Hargis et al. 1992, Goldschmidt \& Goldschmidt 2017).

Due to the low degree of differentiation, $7.9 \%$ of all evaluated neoplasms were diagnosed with non-specific neoplasia. In these cases, immunohistochemistry is indicated for the identification of the cell origin, a test little used due to the high cost and low availability in the laboratories. However, in some situations, the histological aspects and the biological behavior of the neoplasm may be sufficient for the clinical veterinarian to determine the treatment for the animal (Meirelles et al. 2010).

The evaluation of the distribution of neoplasms according to breeds, age groups, anatomical locations, and sex confirmed the previously reported predispositions such as sebaceous adenoma in Cocker Spaniels and in the head, hepatoid neoplasms in males (Goldschmidt \& Goldschmidt 2017), mast cell tumor in Boxers and Labrador Retrievers (Kiupel 2017), histiocytoma in young animals, and lipoma in females (Hendrick 2017). However, due to the limited knowledge about the dog population in the studied region, there is a possibility of environmental bias in the samples.

In the present study, groups of neoplasms showed an association with different epidemiological features. It is suggested that these results were observed due to the main histological diagnoses found in the analyzed variables such as mast cell tumor in the limbs, thorax and scrotum, lymphoma in multiple locations, and histiocytoma in dogs aged $<1$ year. 
It is noteworthy that some results may vary due to the large number of neoplasms with different behaviors in each group.

Frequent association between the size of the cutaneous neoplasms in dogs and their biological behavior has been previously reported (Lima et al. 2018). However, the growth rate of neoplasms may depend on a number of factors such as blood supply, unknown influence, and hormonal stimulation (Stricker \& Kumar 2010). Therefore, the size of the neoplasm should not be used as a criterion while deciding to send the skin tumors for histological analysis.

Receiving examination requests with incomplete information is part of the routine for numerous veterinary pathology laboratories (Meirelles et al. 2010, Lima et al. 2018). This fact made it impossible to include other data such as the relationship between castration and the occurrence of neoplasms in the present study. It is worth remembering that epidemiological data, clinical history, and macroscopic characteristics of the lesion may help pathological diagnosis in numerous situations.

\section{CONCLUSIONS}

Cutaneous neoplasms constituted a large part of diagnoses in dogs in the metropolitan region of Goiânia, Goiás state. Mast cell tumor, hemangiosarcoma, and squamous cell carcinoma were the most common neoplasms.

In addition to confirming the previously reported predispositions, our results revealed that the groups of neoplasms showed association with different epidemiological features and the size of the neoplasms showed association with the biological behavior.

The present study may encourage new studies in future to improve animal welfare.

Acknowledgements. - The authors are grateful to the "Programa Institucional de Bolsas de Iniciação Científica" (PIBIC) of "Instituto Federal Goiano" for the financial support (scholarship) provided to this study.

Conflict of interest statement. - The authors have no competing interests.

\section{REFERENCES}

Andrade R.L.F.S., Oliveira D.M., Dantas A.F.M., Souza A.P., Nóbrega Neto P.I. \& Riet-Correa F. 2012. Tumores de cães e gatos diagnosticados no semiárido da Paraíba. Pesq. Vet. Bras. 32(10):1037-1040.<http://dx.doi.org/10.1590/ S0100-736X2012001000016>

Bastos R.S.C., Farias K.M., Lopes C.E.B., Pacheco A.C.L. \& Viana D.A. 2017. Estudo retrospectivo de neoplasias cutâneas em cães da região metropolitana de Fortaleza. Revta Bras. Hig. San. Anim. 11(1):39-53. <http://dx.doi.org/10.5935/1981-2965.20170005>

Bostock D.E. 1986. Neoplasms of the skin and subcutaneous tissues in dogs and cats. Brit. Vet. J. 142(1):1-19. <http://dx.doi.org/10.1016/00071935(86)90002-3><PMid:3947927>

Dobson J.M., Samuel S., Milstein H., Rogers K. \& Wood J.L. 2002. Canine neoplasia in the UK: estimates of incidence rates from a population of insured dogs. J. Small Anim. Pract. 43(6):240-246. <http://dx.doi. org/10.1111/j.1748-5827.2002.tb00066.x><PMid:12074288>

Fernandes C.C., Medeiros A.A., Magalhães G.M., Juan Szabó M.P., Queiroz R.P., Silva M.V.A. \& Soares N.P. 2015. Frequência de neoplasias cutâneas em cães atendidos no hospital veterinário da Universidade Federal de Uberlândia durante os anos 2000 a 2010. Biosci. J. 31(2):541-548. <http://dx.doi. org/10.14393/BJ-v31n2a2015-22371>
Goldschmidt M.H. \& Goldschmidt K.H. 2017. Epithelial and melanocytic tumors of the skin, p.88-141. In: Meuten D.J. (Ed.), Tumors in Domestic Animals. 5th ed. John Wiley and Sons, Ames, Iowa. <https://dx.doi. org/10.1002/9781119181200.ch4>

Graf R., Pospischil A., Guscetti F., Meier D., Welle M. \& Dettwiler M. 2018. Cutaneous tumors in swiss dogs: retrospective data from the swiss canine cancer registry, 2008-2013. Vet. Pathol. 55(6):809-820. <http://dx.doi. org/10.1177/0300985818789466><PMid:30131007>

Hargis A.M., Ihrke P.J., Spangler W.L. \& Stannard A.A. 1992. A retrospective clinicopathologic study of 212 dogs with cutaneous hemangiomas and hemangiosarcomas. Vet. Pathol. 29(4):316-328. <http://dx.doi. org/10.1177/030098589202900406><PMid:1514218>

Hendrick M.J. 2017. Mesenchymal tumors of the skin and soft tissues, p.142175. In: Meuten D.J. (Ed.), Tumors in Domestic Animals. 5th ed. John Wiley and Sons, Ames, Iowa. <https://dx.doi.org/10.1002/9781119181200.ch5>

Kaldrymidou H., Leontides L., Koutinas A.F., Saridomichelakis M.N. \& Karayannopoulou M. 2002. Prevalence, distribution and factors associated with the presence and the potential for malignancy of cutaneous neoplasms in 174 dogs admitted to a clinic in Northern Greece. J. Vet. Med. A 49(2):8791. <PMid:11958472>

Kiupel M. 2017. Mast cell tumors, p.176-202. In: Meuten D.J. (Ed.) Tumors in Domestic Animals. 5th ed. John Wiley and Sons, Ames, Iowa. <https://dx.doi.org/10.1002/9781119181200.ch6>

Lima S.R., Stocco M.B., Rondelli L.A.S., Silva G.S., Lopes R.S., Furlan F.H. Colodel E.M. \& Pescador C.A. 2018. Neoplasmas cutâneas em cães: 656 casos (2007-2014) em Cuiabá, MT. Pesq. Vet. Bras. 38(7):1405-1411. <http://dx.doi.org/10.1590/1678-5150-PVB-5534>

Machado G.A.C., Fontes T.N., Larangeira D.F., Estrela-Lima A., Moreira E.L.T., Ribeiro L.S., Pinto M.P.R. \& Peixoto T.C. 2018. Incidence of skin tumors in dogs in Salvador, Bahia state, Brazil (2007-2016). Pesq. Vet. Bras. 38(11):2139-2145.<http://dx.doi.org/10.1590/1678-5150-PVB-5686>

Martinez M.A.R., Francisco G., Cabral L.S., Ruiz R.G. \& Festa Neto C. 2006 Genética molecular aplicada ao câncer cutâneo não melanoma. Anais Bras. Dermatol. 81(5):405-419. <http://dx.doi.org/10.1590/S036505962006000500003>

Meirelles A.E.W.B., Oliveira E.C., Rodrigues B.A., Costa G.R., Sonne L., Tesser E.S. \& Driemeier D. 2010. Prevalência de neoplasmas cutâneos em cães da região metropolitana de Porto Alegre/RS: 1.017 casos (2002-2007) Pesq. Vet. Bras. 30(11):968-973. <http://dx.doi.org/10.1590/S0100736X2010001100011>

Mukaratirwa S., Chipunza J., Chitanga S., Chimonyo M. \& Bhebhe E. 2005 Canine cutaneous neoplasms: prevalence and influence of age, sex, and site on the presence and potential malignancy of cutaneous neoplasms in dogs from Zimbabwe. J. S. Afr. Vet. Ass. 76(2):59-62. <PMid:16108522>

Murphy S. 2006. Skin neoplasia in small animals. 1. Principles of diagnosis and management. Clin. Pract. 28(5):266-227. <http://dx.doi.org/10.1136/ inpract.28.5.266>

Nardi A.B., Rodaski S., Sousa R.S., Costa T.A., Macedo T.R., Rodigheri S.M., Rios A. \& Piekarz C.H. 2002. Prevalência de neoplasias e modalidades de tratamentos em cães, atendidos no hospital veterinário da Universidade Federal do Paraná. Arch. Vet. Sci. 7(2):15-26. <http://dx.doi.org/10.5380/ avs.v7i2.3977>

Pakhrin B., Kang M.S., Bae I.H., Park M.S., Jee H., You M.H., Kim J.H., Yoon B.I, Choi Y.K. \& Kim D.Y. 2007. Retrospective study of canine cutaneous tumors in Korea. J. Vet. Sci. 8(3):229-236. <http://dx.doi.org/10.4142/ jvs.2007.8.3.229><PMid:17679768>

R Core Team. 2019. R: aA language and environment for statistical computing. R Foundation for Statistical Computing, Vienna, Austria. Available at <http://www.R-project.org/> Accessed on August 24, 2020. 
Rothwell T.L.W., Howlett C.R., Middleton D.J., Griffiths D.A. \& Duff B.C. 1987. Skin neoplasms of dogs in Sydney. Aust. Vet. J. 64(6):161-164. <http://dx.doi.org/10.1111/j.1751-0813.1987.tb09673.x><PMid:3115242>

Scattone N.V. \& Fava C.D. 2014. Casuística de tumores cutâneos em cães diagnosticados pelo Laboratório de Anatomia Patológica do Instituto Biológico, São Paulo, Brasil, no período de 1996 a 2013. Revta Acad., Ciênc. Agrár. Ambient. 12(4):296-305. <http://dx.doi.org/10.7213/ academica.12.04.A008>

Silva T.R., França T.N., Cunha B.R.M., Prado J.S. \& Brito M.F. 2011. Neoplasias Cutâneas de Cães Diagnosticadas no Laboratório de Histopatologia da Universidade Federal Rural do Rio de Janeiro de 1995 a 2005. Revta Ciênc. Vida 31(1):100-110.
Souza T.M. 2005. Estudo retrospectivo de 761 tumores cutâneos em cães. Dissertação de Mestrado, Universidade Federal de Santa Maria, Santa Maria, RS. 280p.

Souza T.M., Fighera R.A., Irigoyen L.F. \& Barros C.S.L. 2006. Estudo retrospectivo de 761 tumores cutâneos em cães. Ciência Rural 36(2):555-560. <http://dx.doi.org/10.1590/S0103-84782006000200030>

Stricker T.P. \& Kumar V. 2010. Neoplasia, p.259-330. In: Kumar V., Abbas A.K., Fausto N. \& Aster J.C. (Eds), Robbins and Cotran Robbins basic pathology. 8th ed. W.B. Saunders Elsevier, Philadelphia.

Welle M.M., Bley C.R., Howard J. \& Rüfenacht S. 2008. Canine mast cell tumours: a review of the pathogenesis, clinical features, pathology and treatment. Vet. Dermatol.19(6):321-339. <http://dx.doi.org/10.1111/j.1365-3164.2008.00694.x> 